\title{
Specificity of Escherichia coli endoribonuclease RNase $E$ : in vivo and in vitro analysis of mutants in a bacteriophage T4 mRNA processing site
}

\author{
Claude P. Ehretsmann, ${ }^{1}$ Agamemnon J. Carpousis, ${ }^{2}$ and Henry M. Krisch ${ }^{3}$ \\ Department of Molecular Biology, University of Geneva, 1211 Geneva 4, Switzerland
}

Endoribonuclease RNase $\mathrm{E}$ has an important role in the processing and degradation of bacteriophage $\mathrm{T} 4$ and Escherichia coli mRNAs. We have undertaken a mutational analysis of the -71 RNase E processing site of T4 gene 32. A series of mutations were introduced into a synthetic T4 sequence cloned on a plasmid, and their effects on processing were analyzed in vivo. The same mutations were transferred into $\mathrm{T} 4 \mathrm{by}$ homologous recombination. In both the plasmid and the phage contexts the processing of the transcripts was similarly affected by the mutations. Partially purified RNase $E$ has also been used to ascertain the effect of these mutations on RNase E processing in vitro. The hierarchy of the efficiency of processing of the various mutant transcripts was the same in vivo and in vitro. These results and an analysis of all of the known putative RNase $E$ sites suggest a consensus sequence RAUUW ( $R=A$ or $G ; W=A$ or $U$ ) at the cleavage site. Modifications of the stem-loop structure downstream of the -71 site indicate that a secondary structure is required for RNase E processing. Processing by RNase $\mathrm{E}$ was apparently inhibited by sequences that sequester the site in secondary structure.

[Key Words: Bacteriophage T4 gene 32; mRNA degradation; RNA processing; ribonuclease E]

Received August 29, 1991; revised version accepted November 14, 1991.

In prokaryotes, mRNA decay appears to be mediated by the coordinated action of exonucleases and endonucleases (for review, see Belasco and Higgins 1988). Polynucleotide phosphorylase and RNase II are the two major $3^{\prime} \rightarrow 5^{\prime}$ exonucleases involved in mRNA turnover (Donovan and Kushner 1986). Their processive action is impeded by secondary structures as, for example, a stem-loop structure at the $3^{\prime}$ end of a transcript (Newbury et al. 1987; Plamann and Stauffer 1990). Endonucleases can remove such secondary structures and thus generate new $3^{\prime}$ ends that are susceptible to further exonucleolytic degradation (Schmeissner et al. 1984; Régnier and Hajnsdorf 1991). At least in some cases, an endonucleolytic cleavage triggers the decay of the message. Endoribonuclease RNase III is known to initiate the decay of a few specific mRNAs (Schmeissner et al. 1984; Portier et al. 1987; Bardwell et al. 1989; Régnier and Grunberg-Manago 1989|. Other endonuclease activities have been described that are believed to be involved in the degradation of specific mRNAs /Cannistraro and Kennel 1989; Lundberg et al. 1990|, but their role in glob-

Present addresses: ${ }^{1}$ The Salk Institute for Biological Studies, San Diego, California 92186-5800; ${ }^{3}$ Centre de Recherche de Biochimie et Génétique Cellulaire du Centre National de la Recherche Scientifique, 31062 Toulouse, France.

${ }^{2}$ Corresponding author. al mRNA decay is not yet clear. RNase $\mathrm{E}$ is the only endoribonuclease implicated thus far in general mRNA turnover. In bacteriophage T4, Escherichia coli RNase E has a major role in the functional and chemical decay of many phage mRNAs (Mudd et al. 1990a). Recently, studies with a thermosensitive mutation have implicated RNase $\mathrm{E}$ in the decay of $E$. coli mRNA as well (Mudd et al. 1990b; Babitzke and Kushner 1991). ams (altered mRNA stability; Ono and Kuwano 1979, 1980) is the only other mutation known to affect the global decay of $E$. coli mRNAs. The ams mutation has recently been shown to map at the same genetic locus (rne) that is believed to encode the structural gene for RNase E (Mudd et al. 1990b; Babitzke and Kushner 1991). The rne gene has been cloned and sequenced, but the exact size of its open reading frame is still in dispute (Chauhan et al. 1991; Claverie-Martin et al. 1991). The size of the gene product determined by SDS-PAGE is $110 \mathrm{kD}$ (ClaverieMartin et al. 1989; Taraseviciene et al. 1991).

RNase E was initially characterized as the enzyme that processes the precursor of 5S rRNA /Ghora and Apirion 1978). Accordingly, RNase E will be defined here as the activity that cleaves the $9 \mathrm{~S}$ precursor of $5 \mathrm{~S}$ rRNA. Recently a number of mRNAs were shown to contain rne-dependent cleavage sites that are abolished in the $r n e^{t s}$ or $a m s^{\text {ts }}$ strains at the nonpermissive temperature. 
Cleavage at an rne-dependent site can result in a processed transcript that is relatively stable as, for example, the T4 gene 32 (Mudd et al. 1988), the $\operatorname{dicF}$ (Faubladier et al. 1990), and the gltX mRNAs (Brun et al. 1990). RNase E processing of the T4 genes 59 and orfC /Carpousis et al. 1989 ) and of the E. coli rpsO transcripts (Régnier and Hajnsdorf 1991) apparently initiates the decay of sequences upstream of the cleavage site.

At present, it is not clear what features of an mRNA are necessary for recognition and cleavage by RNase E. By comparing the RNase E sites from the 5S rRNA and the inhibitor of ColEI plasmid replication RNAI, a decameric consensus sequence was proposed for the site of cleavage (Tomcsànyi and Apirion 1985). In a further compilation of all the identified rne-(and ams)-dependent cleavage sites, some homology can only be found in a 5-bp sequence around the cleavage site (Table 1). One or more cleavages occurs within the RAUUW consensus sequence, usually in the central AUU. All of the processed RNAs have the potential to form a stable secondary structure slightly downstream of this sequence. However, some of the rne-dependent sites listed in Table 1 must be considered to be only putative sites because cleavage by $\mathrm{RNase} \mathrm{E}$ in vitro has not been demonstrated. A few rne-dependent sites are apparently not cleaved by partially purified RNase E (Pragai and Apirion 1982; Gurevitz et al. 1983; Nilsson et al. 1988; Subbarao and Apirion 1989) but by other activities like RNase K (Lunberg et al. 1990), RNase F (Gurevitz et al. 1982), or RNase III (Srivastava et al. 1990).

To elucidate the sequences and structures required for recognition and processing by RNase E, we have altered either the cleavage sequence or the downstream secondary structure of an rne-dependent site and analyzed the processing of these mutants. The cleavage site studied is located 71 bp upstream of the bacteriophage T4 gene 32 start codon (Mudd et al. 1988). The mutations at the -71 site were introduced in both phage $\mathrm{T} 4$ and in a small segment of T4 sequence carried on a plasmid. Analysis of these mutated RNase E sites was also performed in vitro with partially purified enzyme. We found that a 115nucleotide T4 RNA was sufficient for RNase E processing at the -71 site and that the effects of the mutations on processing were similar both in vivo and in vitro. This analysis indicates that the sequence at the cleavage site and the downstream secondary structure are both essential for RNase E cleavage. Alteration of the RAUUW consensus cleavage sequence often resulted in a reduction in, rather than a complete loss of, processing. Sequestering of the site in secondary structure appears to reduce processing efficiency significantly. We discuss the implications of these features on the mechanism of action of RNase E.

\section{Results}

Construction of a plasmid containing the -71 rne-dependent cleavage site

A 115-bp sequence of T4 containing the wild-type
Table 1. Compilation of rne-dependent sites

\begin{tabular}{|c|c|c|}
\hline Site & $\begin{array}{l}\text { Cleavage } \\
\text { sequence }\end{array}$ & References \\
\hline $\begin{array}{c}\text { RNase E site } \\
\text { consensus }\end{array}$ & $\underset{A}{G} A \cup U \begin{array}{l}U \\
A\end{array}$ & \\
\hline $9 \mathrm{Sa}$ & $A^{\nabla} \mathrm{A} \cup \cup U$ & $\begin{array}{l}\text { Ghora and Apirion } \\
(1978)\end{array}$ \\
\hline $9 \mathrm{Sb}$ & $\mathrm{A}^{\nabla} \mathrm{A} \cup \mathrm{A} A$ & $\begin{array}{l}\text { Ghora and Apirion } \\
\text { (1978) }\end{array}$ \\
\hline RNA I & $\mathrm{U}^{\nabla} \mathrm{A} U \mathrm{U} U$ & $\begin{array}{l}\text { Tomcsányi and } \\
\text { Apirion (1985) }\end{array}$ \\
\hline T4 gene $32(-71)$ & $\mathrm{A}^{\nabla} \mathrm{A} \cup \mathrm{U} \mathrm{A}$ & Mudd et al. (1988) \\
\hline T4 gene $59(-1340)$ & $G^{\nabla} A^{\nabla} U \cup A$ & $\begin{array}{l}\text { Carpousis et al. } \\
\text { (1989) }\end{array}$ \\
\hline $\operatorname{dicF}$ & A A $U^{\nabla} U U$ & $\begin{array}{l}\text { Faubladier et al. } \\
\qquad(1990)\end{array}$ \\
\hline gltX & A $A^{\nabla} U^{\nabla} U^{\nabla} U$ & Brun et al. $(1990)$ \\
\hline gltX & $G^{\nabla} A \cup U U$ & Brun et al. $(1990)$ \\
\hline fl D & $U A^{\nabla} U^{\nabla} G^{\nabla} U$ & Kokoska et al. (1990) \\
\hline fl E & A $A^{\nabla} U^{\nabla} C U$ & Kokoska et al. (1990) \\
\hline fl $\mathrm{F}$ & $G A^{\nabla} U^{\nabla} U U$ & Kokoska et al. $(1990)$ \\
\hline fl G & A $A^{\nabla} U^{\nabla} U U$ & Kokoska et al. $(1990)$ \\
\hline $\mathrm{T} 4$ gene $32(+831)$ & $\mathrm{G}^{\nabla} \mathrm{A} \cup \mathrm{U} \mathrm{U}$ & Loayza et al. (1991) \\
\hline $\mathrm{T} 4$ gene $55 / \alpha \mathrm{gt}$ & $\mathrm{A}^{\nabla} \mathrm{A} \cup \mathrm{U} \mathrm{C}$ & Loayza et al. (1991) \\
\hline $\mathrm{T} 2$ gene $32(-76)$ & $\mathrm{A}^{\nabla} \mathrm{A}^{\nabla} \mathrm{U}^{\nabla} \mathrm{U} \quad \mathrm{A}$ & Loayza et al. (1991) \\
\hline rpsO-pnp (M2) & $A G^{\nabla} U U U$ & $\begin{array}{l}\text { Régnier and } \\
\text { Hajnsdorf (1991) }\end{array}$ \\
\hline rpsO-pnp (M) & $A A^{\nabla} G C U$ & $\begin{array}{l}\text { Régnier and } \\
\text { Hajnsdorf (1991) }\end{array}$ \\
\hline $\operatorname{rps} T(301)$ & $G^{\nabla} A \cup C G$ & Mackie (1991) \\
\hline $\operatorname{omp} A \mathrm{~A}^{\star}$ & $\mathrm{A}^{\nabla} \mathrm{C} \cup \mathrm{U} \mathrm{U}$ & Nilsson et al. $\{1988\}$ \\
\hline ompA $\mathrm{C}^{\star}$ & $G^{\nabla} A \cup U U$ & Nilsson et al. (1988) \\
\hline ompA $\mathrm{D}^{\star}$ & $\mathrm{U}^{\nabla} \mathrm{A} \in \mathrm{U} U \mathrm{U}$ & Nilsson et al. (1988) \\
\hline $10 \mathrm{Sa}^{\star}$ & $G A^{\nabla} U^{\nabla} U^{\nabla} A$ & $\begin{array}{l}\text { Chauhan and Apirion } \\
\{1989\}\end{array}$ \\
\hline $10 \mathrm{Sb}^{*}$ & ${ }^{\nabla} \mathrm{G} A \cup \cup U$ & Gurevitz et al. (1983) \\
\hline $10.1 S^{*}$ & $\mathrm{C} \mathrm{A}^{\nabla} \mathrm{A} A \mathrm{~A}$ & $\begin{array}{l}\text { Pragai and Apirion } \\
\text { (1982) }\end{array}$ \\
\hline
\end{tabular}

Sequences near the point of cleavage have been aligned to give maximum homology to the RNase E site consensus sequence given at the top. The position of the cleavage is indicated for each site by a wedge. Only the first three sites and the T4 sites $-1340,-71$, and +831 have been demonstrated to be substrate for RNase $\mathrm{E}$ in vitro. The asterisks (*) indicate sites that are apparently not cleaved by partially purified RNase $\mathrm{E}$ in vitro (see text). These sites were not considered in compiling the consensus sequence. The rpsT site is cleaved by an activity that is thermosensitive when extracted from $a m s^{\text {ts }}$ strain but that has not yet been shown to process the 9S RNA.

gene $32-71$ site was synthesized from overlapping synthetic oligonucleotides and inserted in the polylinker of pUC18 (see Materials and methods). This sequence extends from nucleotide -95 to +20 of gene $32 \mid+1$ being the first base in the initiation codon of gene 32). To simplify the analysis of $5^{\prime}$ ends, the -45 promoter of gene 32 that is active in uninfected cells (Belin et al. 1987) was inactivated by a change in the Pribnow box $(A \rightarrow G$ at -52 ). Furthermore, to facilitate the introduction of $\mathrm{mu}$ tations, an HpaI restriction site was created by a singlebase-pair change at -27 from $\mathrm{T}$ to $\mathrm{C}$ (Fig. 1). These 
A

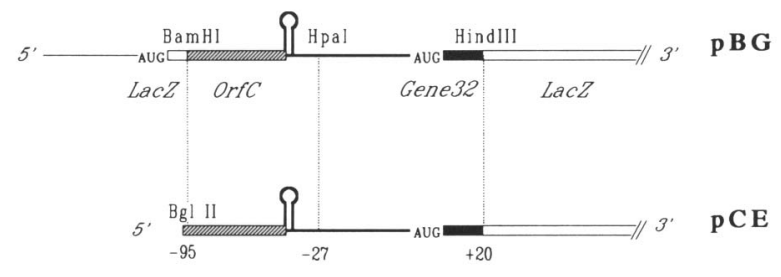

B

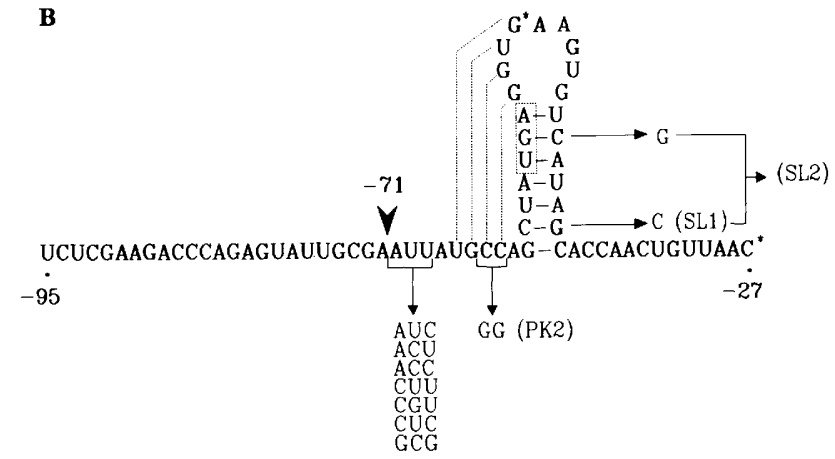

Figure 1. (A) Map of the hybrid lacZ-gene 32 mRNAs transcribed from the lac promoter of the pBG and pCE plasmids. Solid and hatched boxes represent, respectively, gene 32- and orf $C$-coding sequences. Nontranslated regions from the $\mathrm{T} 4$ sequence are indicated by a thick line. The stem-loop of the -71 RNase E site is indicated at the end of the T4 orfC sequence las shown in detail in $B$, orf $C$ actually terminates within the stem). Open boxes represent the lacZ-coding sequence. The thin line indicates the 55-nucleotide nontranslated leader sequence of the lac transcript. The AUG start codon of the lacZ gene and the gene 32-lac $Z$ fusion are shown. $(B)$ The $\mathrm{T} 4$ sequence from -95 to -27 containing the RNase E cleavage site. The thick vertical arrowhead indicates the position of the RNase E cleavage. The boxed termination codon (UGA) is the end of T4 orfC. The dotted lines indicate the base-pairing involved in the formation of the pseudoknot. The two nucleotides marked with an asterisk (*) at positions -52 and -27 have been modified from the wild-type T4 sequence (see text). The mutations introduced in the -71 RNase E site are shown. The names given to the mutants affecting the secondary structure are indicated in parentheses. The mutations restoring the secondary structure by complementary mutations in the stem (SL1r and SL2r) or in the pseudoknot (PK2r) are not indicated. In the SLlr mutation, the nucleotide at position -61 is changed from C to G. The SL2r mutation also contains a change at position $-57(\mathrm{G} \rightarrow \mathrm{C})$. The mutation PK2r corresponds to two changes at positions -54 and -55 (both $\mathrm{G} \rightarrow \mathrm{C}$ ).

changes did not alter the processing of the mRNA at the -71 site (see below). In the resulting construct, $\mathrm{pBG}$, transcription from the lac promoter yields a hybrid transcript containing the 5 ' leader of lac mRNA followed by the T4 segment and the sequence encoding the lac $\alpha$ peptide (Fig. 1). The translation initiating from lac $Z$ is terminated by the T4 orfC stop codon at -58 , but an $\alpha$ peptide is synthesized from the gene 32 initiation codon.

To verify that the T4 segment in this plasmid includes the sequence necessary for processing at the -71 site, the $5^{\prime}$ ends of the transcripts were analyzed by primer extension. The rne dependence of the processing was confirmed by transforming both the $r n e^{+}$strain and the $r n e^{\text {ts }}$ strain in which RNase $\mathrm{E}$ activity is reduced significantly at the nonpermissive temperature (Apirion 1978). Total RNA was extracted at $30^{\circ} \mathrm{C}$ and at $43^{\circ} \mathrm{C}$, and the $5^{\prime}$ ends of the hybrid T4-lac transcript were analyzed with a primer complementary to nucleotides from +1 to +21 of gene 32. A $5^{\prime}$ end at -71 was detected in the $r n e^{+}$ strain at both $30^{\circ} \mathrm{C}$ and $43^{\circ} \mathrm{C}$ (Fig. 2). In the mutant $r n e^{\text {ts }}$ strain, this band disappeared at the nonpermissive temperature. Thus, the synthetic -71 site is processed at the correct location, and this processing is rne dependent. Although the 115-bp region of gene 32 is sufficient for processing at the -71 site, the efficiency of the processing appeared to be lower than that observed in the phage T4 (Mudd et al. 1988). As will be shown below, it is likely that the $5^{\prime}$ lac sequence in this construct interferes with the processing at the -71 site by forming a secondary structure with the cleavage site.

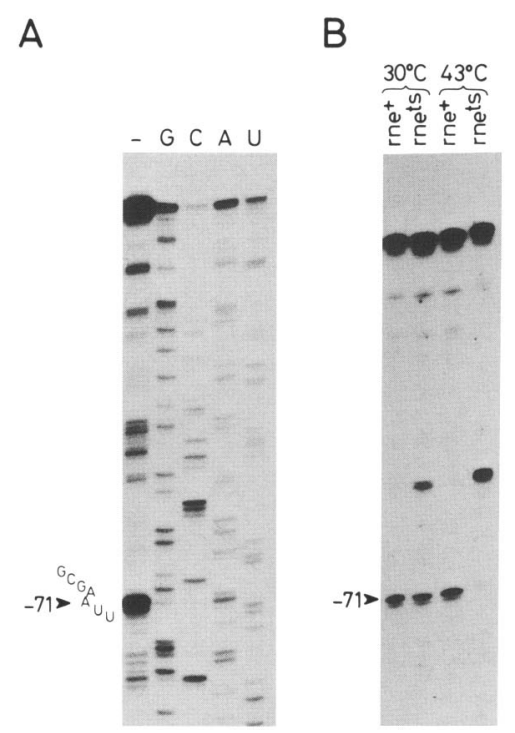

Figure 2. (A) The precise $5^{\prime}$ ends of the hybrid lacZ-gene 32 mRNA. Total RNA was isolated at $30^{\circ} \mathrm{C}$ from an $\mathrm{rne}^{+}$strain carrying the plasmid pBG. The RNA was hybridized to a $5^{\prime}-$ end-labeled primer complementary to nucleotides +1 to +21 of the gene 32 sequence. The products of extension with reverse transcriptase were electrophoresed on a sequencing gel (first lane) alongside a dideoxy sequencing ladder (lanes $G, C, A, U)$. In addition to the uppermost band, which corresponds to the start of the transcript, a major $5^{\prime}$ end at -71 is detected in the first lane (arrowhead). Although the main cleavage is at -71 , a weaker band at -70 could reflect heterogenous cutting by RNase $\mathrm{E}$ or premature termination by the reverse transcriptase. The nucleotide sequence indicated at the -71 cleavage is that of the gene 32-coding strand. $(B)$ Processing of the -71 site depends on RNase $\mathrm{E}$. The $5^{\prime}$ end of the hybrid transcript in $r n e^{+}$ and $r n e^{\text {ts }}$ strain is shown. The $5^{\prime}$ ends were analyzed as in $A$, but total RNA was extracted from $r n e^{+}$and $r n e^{\text {ts }}$ strains bearing the plasmid $\mathrm{pBG}$, at both $30^{\circ} \mathrm{C}$ and $43^{\circ} \mathrm{C}$. An additional $5^{\prime}$ end of unknown origin is detected at -91 (CG/AAG) in the $m e^{\text {ts }}$ strain but not in the isogenic rne $e^{+}$strain. 
In vivo analysis of mutant derivatives of the -71 synthetic site

Those features thought to be involved in rne-dependent processing were altered by mutation. Fragments containing mutations in the -71 site were synthesized with oligonucleotides and used to replace the corresponding region in the parent plasmid pBG / see Materials and methods). The sequence AAUUA flanking the -71 cleavage site conforms to the consensus cleavage sequence (see Table 1). We have shown previously that mutants with the AUU sequence changed to GCG, CUC, or CGU were not processed (Ehretsmann et al. 1990), indicating that the sequence at the cleavage site is important. The second common feature of rne-dependent sites is the presence of a secondary structure downstream of the cleavage site. The existence of a stem-loop downstream of the -71 site has been confirmed by enzymatic and chemical probing (McPheeters et al. 1988). We have introduced changes in the T4 segment to disrupt the stem-loop. For the base substitutions that disrupt 1 (SL1) or $2 \mathrm{bp}$ (SL2) in the stem, processing at -71 was not detected (Fig. 3, lanes 2,4). Additional mutations that restored base-pairing by a complementary mutation were processed efficiently (Fig. 3, lanes 3,5), and this cleavage was rne dependent (data not shown). This result shows that the stem-loop structure is essential for rnedependent processing. Because the mutants with the re-

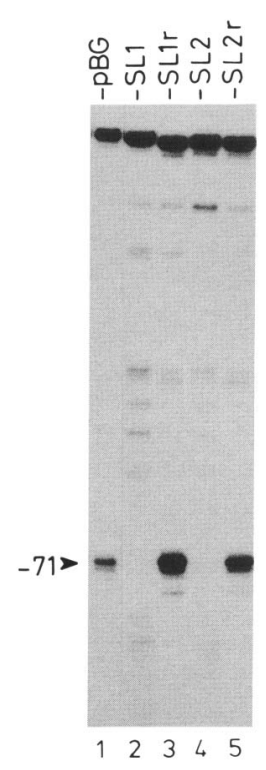

Figure 3. Analysis of the processing of the stem-loop mutants. The $5^{\prime}$ ends were analyzed by primer extension of RNA extracted at $30^{\circ} \mathrm{C}$ from $\mathrm{mne}^{+}$strains bearing different mutant plasmids. (Lane 1) The processing of the hybrid transcript carrying the wild-type -71 site $(\mathrm{pBG})$; (lanes 2,4$)$ the $5^{\prime}$ ends of the transcripts with single (SL1) or double (SL2) base changes that disrupt the stem (see Fig. 1A); (lanes 3,5) the processing of the transcripts in which the secondary structure has been restored by the appropriate complementary mutation to SL1 (SLlr) or SL2 (SL2r). stored stem (SL1r and SL2r) were also cleaved, there is apparently no sequence specificity for the bases mutated. Furthermore, examination of the stems downstream of rne-dependent cleavage sites does not reveal any striking sequence homology in the secondary structure. The higher efficiency of processing in the SL1r and SL2r mutants could be the result of the suppression of a secondary structure that interferes with processing in pBG (see next section).

The low level of the -71 processed species in SL1 and SL 2 can be explained if these transcripts with an altered sequence are extremely unstable. Although this processed product was present in a very low amount, its stability was measured by analyzing the $5^{\prime}$ ends at different times after rifampicin treatment (data not shown). The stability was comparable to the processed wild-type transcript. Thus, it is unlikely that the effect of the SLl and SL2 mutations is the result of rapid degradation of the processed mRNA.

\section{Evidence that alternative secondary structure can reduce processing}

When the hybrid lac-gene 32 mRNA transcribed from the lac promoter is folded using the Zuker program (Zuker and Stiegler 1981), a stable secondary structure is predicted that involves base-pairing of 5' lac sequences with the cleavage site and part of the stem (Fig. 4B). In this folded structure, the cleavage site is sequestered, and formation of the normal stem-loop is prevented. If a significant proportion of the transcripts were folded in this manner, this would explain the relatively low efficiency of processing at the -71 site observed in the hybrid transcript. To examine the possible role of this secondary structure, we constructed a new plasmid in which these lac sequences are deleted. The transcripts originating from this new plasmid (pCE) start directly with the T4 sequence (Fig. 1A). Comparison of the $5^{\prime}$ ends of the wild-type pCE and pBG hybrid mRNAs revealed that the shorter transcript was processed with a higher efficiency (Fig. 4A). This processing was rne dependent (data not shown). Furthermore, in the pBG mutants bearing an altered stem sequence (SLlr and SL2r), the structure shown in Figure $4 \mathrm{~B}$ is probably disrupted from -121 to -114 , thus allowing the normal stem to fold properly. In these two mutants the processing was more efficient than in the wild type (see Fig. 3). Taken together, these results suggest that the alternative mRNA secondary structure shown in Figure 4B is responsible for the low efficiency of processing observed in pBG. Processing is probably also affected when the cleavage site alone is trapped in a secondary structure, because processing of the pBG mutants SL2r and, possibly, SLlr occurred at lower levels than for pCE /cf. Fig. 3, lanes 3 and 5 with Fig. 4, lane 2).

Additional mutations in the -71 cleavage sequence were introduced in this new construct. Mutants changing the AUU at the cleavage site to AUC or ACU were processed normally at the -71 site (data not shown). A mutant changing the sequence to ACC was processed at 
A

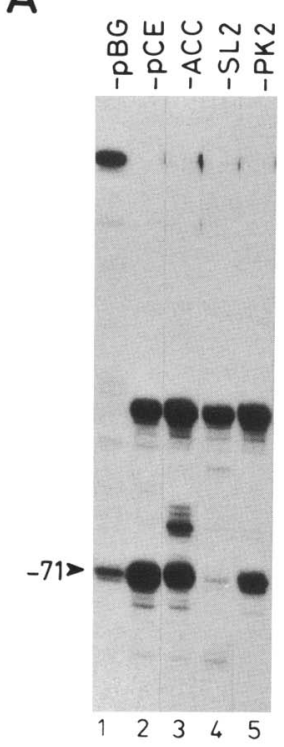

B

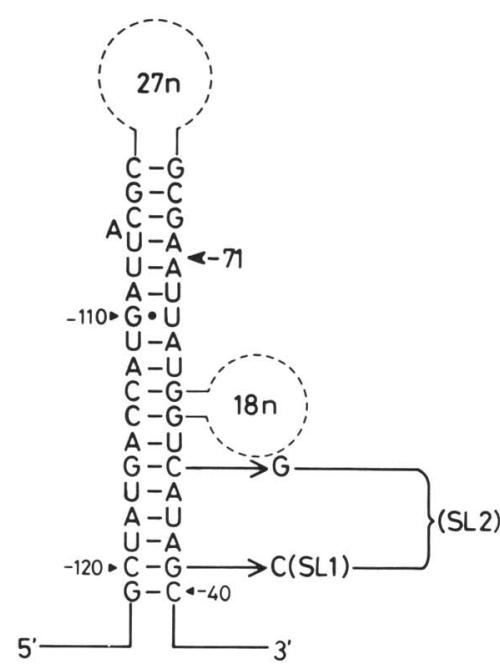

Figure 4. $(A)$ Comparison of processing of transcript from $\mathrm{pBG}$ and $\mathrm{pCE}$ and analysis of the mutants in the pCE plasmid. RNA was extracted at $30^{\circ} \mathrm{C}$ from $\mathrm{rne}^{+}$strains bearing different plasmids. The $5^{\prime}$ ends were analyzed as indicated in Fig. 2. (Lane 1) RNA from cells carrying $\mathrm{pBG}$; (lanes 2-5) RNA from cells carrying pCE (lane 2) and the pCE mutations of the -71 site (mutations are indicated above each lane). The primary transcript is 55 nucleotides shorter in the pCE constructs than in $\mathrm{pBG}$ /see text $)$. $(B)$ Possible secondary structure involving the -71 RNase E site and upstream lac sequence in the pBG constructs. The lac sequence from -121 to -103 is shown base-paired with the -71 cleavage site $(-75$ to -66$)$ and with the $3^{\prime}$ part of the stem $(-47$ to -40$)$, thus preventing base-pairing with nucleotides -56 to -62 and the formation of the stem-loop. The names of the mutations that disrupt the gene 32 stem-loop are indicated in parentheses. These mutations also destabilize the alternative secondary structure. Thus, in mutants SLlr and SL2r, which also have complementary mutations at -60 and -57 , the formation of the stem-loop is restored and the lac sequence upstream can no longer interfere with this structure.

-71 although at a lower efficiency than that of the wildtype sequence (Fig. 4A, lane 3). This processing is rne dependent because the cleavage at -71 did not appear at the nonpermissive temperature in the $r n e^{\text {ts }}$ strain (data not shown). This result is surprising because this mutation introduces two changes within the highly conserved AUU of the RAUUW consensus sequence. This decrease in processing efficiency was associated with the appearance of an additional $5^{\prime}$ end at -78 in the sequence U/AUUG. Furthermore, the presence of this band was rne dependent (data not shown). As in the previous construct, a double mutation that disrupts the stem-loop (SL2) strongly reduces the processing (Fig. 4A, lane 4). Some new mutations affecting the secondary structure were also introduced in this shorter hybrid construct. The target for this mutational analysis was the RNA pseudoknot just downstream of the -71 cleavage sequence (McPheeters et al. 1988). Four bases in the loop

can pair with 4 bases located between -71 and the stem (Fig. 1). This additional base-pairing probably increases the overall stability of the secondary structure downstream of the -71 site. This pseudoknot appears to be of biological significance, as this structure, but not the sequence, is conserved in the T-even related phages downstream of an rne-dependent site analoguous to the -71 site (Loayza et al. 1991). We have noticed that several other $r n e$-dependent sites, like the -1340 site in T4 gene 59 (Carpousis et al. 1989) and the dicF site, (Faubladier et al. 1990) also have the potential to form a pseudoknot. We examined the possible role of this structure in RNase E processing at the -71 site by introducing mutations that partially disrupt the 4 bp between the loop and the sequence upstream of the stem. A pseudoknot double mutant (PK2; see Fig. 1) hybrid mRNA was cleaved at the -71 site, although apparently with a lower efficiency than the wild type (Fig. 4, lane 5). Thus, the pseudoknot itself does not seem to be an essential element for recognition and processing by RNase $\mathrm{E}$ because processing still occurred in its absence. More likely, it increases the stability of the downstream secondary structure that is required for processing by RNase E. The efficiency of processing could depend, at least in part, on the stability of the downstream secondary structure.

\section{T4 phage with mutations in the -71 site}

Several of the mutations at the -71 site were introduced into the phage T4 genome to determine whether they would similarly affect the processing of gene 59 mRNA in a phage infection. The mutations were introduced into $\mathrm{T} 4$ by in vivo homologous recombination using a plasmid containing the mutated -71 cleavage site and several hundred base pairs of flanking wild-type gene 32 sequence (see Materials and methods). The identities of mutant phages were verified by DNA sequencing. These phages were then used to infect $r n e^{+}$or $r n e^{\text {ts }}$ strains (see Materials and methods), and RNase E processing of the gene 32 transcripts was analyzed by primer extension. Two mutations in the AUU cleavage sequence /AUC and CGU) and one mutation disrupting the stem-loop (SL2) were introduced in the phage. A control phage was constructed that has the wild-type sequence at the -71 site (AUU) but contains the two modifications of the gene 32 sequence present in all of the plasmid constructs at positions -27 and -52 (see Fig. 1B). Analysis of the gene 32 mRNA 5 ' ends from the wild-type, control, and mutant phages is shown in Figure 5 . In the wild-type T4 (lane 1) the -71 processed RNA species was detected in addition to the primary transcripts starting at the -205 mot promoter and -145 late promoter (Belin et al. 1987). This processed species was also detected at about the same level in the control phage containing the two changes at -27 and -52 (Fig. 5 , lane 2), indicating that these changes do not affect processing or gene 32 expression. Processing at -71 was observed in the AUG mutant (Fig. 5, lane 3). This processing is rne dependent because it did not occur at $43^{\circ} \mathrm{C}$ in the rne $e^{t s}$ strain (data 


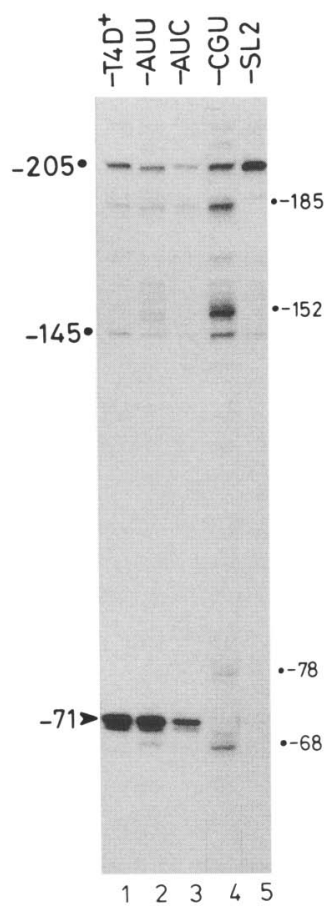

Figure 5. Processing at the -71 site in the mutant phages. Primer extension of RNA extracted from $\mathrm{rne}^{+}$strains $10 \mathrm{~min}$ after infection at $30^{\circ} \mathrm{C}$. (Lane 1) Cells infected with wild-type $\mathrm{T}_{4} \mathrm{D}^{+}$; (lane 2) cells infected with a phage carrying a wild-type -71 site and the two changes at -52 and -27 , which are present in the T4 sequence of the plasmids; (lanes 3-5) cells infected with phage carrying a mutation in the -71 RNase $E$ site as indicated above each lane. The position of the 5 ' ends of the gene 59 mRNAs are indicated. The -205 and -145 transcripts originate from a mot promoter and a late promoter, respectively (Belin et al. 1987). The other cleavages in the CGU mutant (lane 4) are at positions - 185 (AACUC), - 152 (AAUAU), -78 (GUAUU), and -68 (UAUGC).

not shown). The mutation disrupting the stem-loop (SL2) reduced the processing at the -71 site markedly (Fig. 5, lane 5). As expected, the decreased processing resulted in an increase in the amount of the -205 primary transcript. The mutation of the cleavage sequence to CGU suppressed the -71 cleavage, but several new $5^{\prime}$ ends appeared (Fig.5, lane 4). As with the plasmid bearing the ACC mutation (see Fig. 4), the weak band appearing just upstream of -71 corresponds to a $5^{\prime}$ end at -78 (U/AUUG) and is rne dependent (data not shown). The other $5^{\prime}$ ends at $-68,-152$, and -185 are also rne dependent, and each occurs in a sequence resembling the consensus for an RNase E cleavage site (see legend to Fig. 5). Unlike the -152 end, the $5^{\prime}$ ends at -68 and -185 were already visible in very low amounts in the control phage (lane 2) and in pCE (Fig. 4A). Thus, blocking of processing at -71 seems to be correlated with the appearance of new cleavage products or the increase of previously existing minor cleavages. However, this was not observed when the stem-loop was disrupted, suggesting that cleavage at these sites also requires the stem-loop.

\section{In vitro analysis of the processing at the mutated -71 site}

To extend the results obtained in vivo with the -71 site, transcripts carrying different mutations of the -71 site were synthesized in vitro from a $\mathrm{T} 7$ promoter and digested with partially purified RNase E (see Materials and methods). The partially purified RNase E was shown to process 9S RNA to the precursor of 5S rRNA, and this processing was temperature sensitive when proteins were purified from $r n e^{\text {ts }}$ and $a m s^{\text {ts }}$ strains (A.J. Carpousis, G. Van Houwe, C. Ehretsmann, and H. Krisch, in prep.). The synthetic $\mathrm{T} 4$ transcripts used in this in vitro assay are 115 nucleotides long and contain the gene 59 sequence from -95 to +20 . Transcripts containing the wild-type -71 site were incubated at $30^{\circ} \mathrm{C}$ or $45^{\circ} \mathrm{C}$ with RNase E partially purified from both $m e^{+}$and $m e^{+s}$ strains. The resulting products were then analyzed by primer extension. A 5 ' end at -71 was produced when the transcripts were incubated with RNase E purified from $r n e^{+}$strain at either temperature (Fig. 6A). In contrast, this $5^{\prime}$ end was not detected at the nonpermissive temperature when the RNA was incubated with the protein from the $r n e^{\text {ts }}$ strain. These results indicate that in vitro as in vivo this $\mathrm{T} 4$ segment contains the necessary determinants for processing by RNase E. It will be interesting to shorten this RNA further to determine the minimal size of the substrate necessary for recognition and processing by RNase E. In phage $\mathrm{fl}$, the sequences required for ams-dependent cleavages have been delimited to segments ranging from 70 to 130 nucleotides (Blumer and Steege 1989).

Transcripts containing the various mutations were tested in vitro for processing. Figure 6B shows the analysis of the $5^{\prime}$ ends obtained with the different mutant transcripts after incubation at $45^{\circ} \mathrm{C}$ with enzyme from the $r n e^{+}$strain. Processing of transcripts bearing the GCG, CUC, and CGU mutations at the -71 cleavage site was not detected (Fig. 6B, lanes 6, 8, and 9 respectively). The mutant cleavage sequences AUC, ACU, and CUU were processed, although at a much lower efficiency than the wild-type sequence (Fig. 6B, lanes 3, 4, and 7 , respectively). The ACC cleavage site mutant was processed with still lower efficiency (lane 5). The hierarchy of processing efficiency among these mutants was similar in vitro and in vivo. However, the effect of the mutations was more pronounced in vitro. This difference could be the result of a number of factors, including the temperature, the ionic conditions, the amount of enzyme, and the absence of translation in the in vitro system.

As observed in vivo, processing of transcripts with mutations that disrupt the stem (SL1 and SL2) was barely detectable in vitro (lanes 10 and 12, respectively). Complementary mutations that restored the base-pairing of the stem-loop (SLlr and S12r) also restored processing at the -71 site (lanes 11 and 13 , respectively). Interestingly 
A

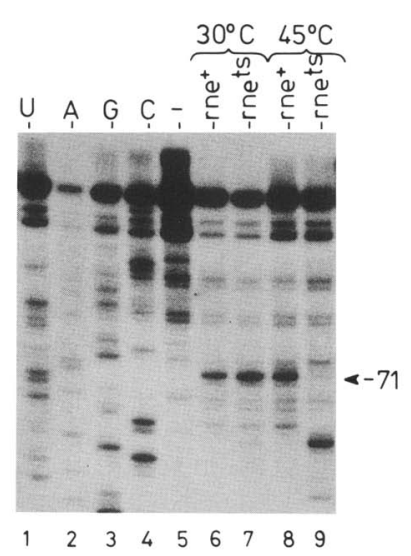

B

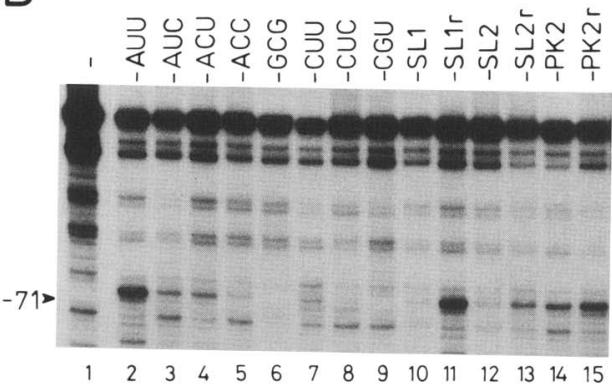

Figure 6. (A) In vitro processing of the -71 site depends on RNase E. Synthetic transcripts bearing the wild-type -71 site were incubated for 15 min with partially purified RNase E, and the $5^{\prime}$ ends were analyzed by extension of a labeled primer complementary to nucleotide +1 to +21 of gene 32. (Lanes 1-4) Dideoxy sequencing ladder; (lane 5) transcript incubated at $30^{\circ} \mathrm{C}$ without enzyme; (lanes 6-9), transcript incubated at $30^{\circ} \mathrm{C}$ or $45^{\circ} \mathrm{C}$ with enzyme partially purified from $m e^{+}$or $m e^{\text {ts }}$ strains. The position of the RNase E cleavage at -71 is indicated. $(B)$ In vitro processing of synthetic transcripts carrying mutations in the -71 RNase E site. Synthetic transcripts were incubated at $45^{\circ} \mathrm{C}$ with partially purified RNase E from $m e^{+}$strain, and the $5^{\prime}$ ends were analyzed as in $A$. (Lane 1) RNA with wild-type -71 site incubated without enzyme. The mutation present in the transcript is indicated above each lane (lanes 2-15).

when incubated at $30^{\circ} \mathrm{C}$ with partially purified RNase E, the stem-loop mutant SL1 transcript was cleaved at -71 (data not shown). A 5-bp stem can still be formed downstream of the cleavage site in this stem-loop mutant. This stem-loop is probably sufficiently stable in vitro to ensure processing at $30^{\circ} \mathrm{C}$ but not at $45^{\circ} \mathrm{C}$. The transcript with the double mutation in the pseudoknot (PK2) was processed with a lower efficiency than the wild type. A transcript with two appropriate mutations in the loop to restore the pseudoknot (pK2r) was processed but, perhaps, not as efficiently as the wild type. Thus, it is possible that some sequence specificity exists in the nucleotides modified in PK2 and PK2r.

\section{Discussion}

Features of the - 71 RNase E site

The results presented here and the analysis of all the known rne-dependent sites indicate that two features are important for processing: an RAUUW consensus cleavage sequence and a double-stranded RNA structure. These features of the -71 processing site of $\mathrm{T} 4$ gene 32 have been altered by mutations. Changing the highly conserved AUU at the cleavage site by 2 or 3 bases to CUC, CGU, or GCG reduced processing in vivo markedly (Ehretsmann et al. 1990). Other mutants, CUU, $\mathrm{ACU}, \mathrm{AUC}$, and ACC, which differ from the AUU consensus sequence by 1 or 2 bases, were still processed at -71 in vivo but with a somewhat lower efficiency. The requirement for a secondary structure downstream of the -71 cleavage site was also investigated. Mutations that disrupt the 7-bp stem-loop reduced processing drastically. Additional mutations that restore the stem also restored processing, suggesting that the secondary structure itself is more important than the exact sequences involved. We have demonstrated that the pseudoknot, formed by the base-pairing of the loop with sequence downstream of the hairpin, is not essential for processing by RNase E. However, the pseudoknot probably contributes to the stability of the double-stranded RNA structure, as disruption of this structure slightly reduces the efficiency of processing. These results suggest that decreasing the stability of the downstream secondary structure, for instance, by abolishing the pseudoknot or reducing the length of the stem, results in lower efficiency of processing. The same results were obtained with all of these mutants in vitro, using partially purified RNase E.

An additional feature of an RNase E site is that processing can be affected by a secondary structure that prevents the formation of the downstream RNA doublestranded region or sequesters the cleavage site in a double-stranded conformation. An influence of RNA structure on the cleavage pattern by RNase $\mathrm{K}$ has also been observed (Lundberg et al. 1990). The possible interference of distant sequences with cleavage by RNase E suggests an interesting mechanism for sequential degradation. An initial endoribonucleolytic cleavage by RNase E or another endonuclease could lead to removal of an interfering sequence and activate cleavage at a distant site by RNase E. Such a cascade of cleavages could mediate the rapid decay of a transcript once a rate-limiting initial event occurred.

Comparison of the -71 site with the other rne-dependent sites

The same features that are essential for processing at -71 are found in all of the other known rne-dependent sites, suggesting that they are necessary for recognition and cleavage by RNase E. However, these sites show some variability both in the cleavage sequence (Table 1) and in the downstream secondary structure. The results 
obtained with our mutants suggest that cleavage efficiency could vary widely, depending on the exact sequence at the cleavage site or on the stability of the secondary structure. Because RNase $\mathrm{E}$ has a general role in chemical mRNA decay in E. coli (Mudd et al. 1990b), its specificity should be broad enough to allow cleavage of a large number of transcripts. Our analysis supports this notion because the sequence required for cleavage does not appear to be rigidly defined.

A number of features of RNase E processing are still unexplained, for example, what determines the exact phosphodiester bond that is cleaved. The modifications made here in the cleavage sequence changed only the efficiency of processing at the site, not the position. The RNA is also not cleaved at a precise distance from the stem-loop structure, as this distance varies considerably in the known RNase E sites. Although the requirement for a secondary structure is established, the precise characteristics of this structure, such as the length of the stem and the size and sequence of the loop, are not yet defined. The secondary structures of the various rne-dependent sites can range from the short hairpin at the -71 site to the complicated branched structure presumed to be present at the -1340 site of gene 59 (Carpousis et al. 1989). No conserved sequences were detected by comparing the nucleotides in the stem or in the loop of the known rne-dependent sites. It is possible that RNase E binds without great specificity to RNA doublestranded structures and then cleaves only if a consensus cleavage sequence is nearby.

It is not clear whether RNase E processing is affected by translation. Processing by RNase $\mathrm{E}$ of sites located within translated regions could be sensitive to the density of translocating ribosomes. Some of the known RNase E sites are located close to sites of translation initiation or termination. This arrangement of the sites could result in translation initiation (or termination) modulating the action of RNase E. RNA-binding proteins could also affect the efficiency of RNase E cleavage. For example, proteins that bind to RNA secondary structure (Romaniuk et al. 1987; Tang and Draper 1989) could either facilitate or inhibit RNase $\mathrm{E}$ action. In the case of the -71 site of gene 32 the binding of gp32 in the vicinity of the processing site may inhibit processing (Mudd et al. 1988).

\section{Processing by the enzyme in vitro}

5S rRNA (Ghora and Apirion 1978), RNAl (Tomcsànyi and Apirion 1985), and the - 71 site (this paper) are the only RNAs shown to be processed in vitro by partially purified RNase E. This list has now been extended to include the -1340 site of T4 gene 59 and the +831 site of gene 32 (A. Carpousis, G. Van Houwe, C. Ehretsmann, and $\mathrm{H}$. Krisch, in prep.). Thus, it seems likely that most of the rne-dependent cleavages observed in vivo will be substrates for RNase $\mathrm{E}$ in vitro. In the simplest hypothesis, the rne gene would encode the RNase E enzyme and cut mRNAs at sites such as those listed in Table 1. The general effect of the rne (or ams) mutations on bulk
mRNA decay would be the direct consequence of the inactivation of this endoribonuclease. However, some sites that are rne dependent in vivo are apparently not processed by RNase E but by other activities [e.g., RNase $\mathrm{K}$ (Lundberg et al. 1990) and RNase F (Gurevitz et al. 1982) This result could be explained by an initial cleavage by RNase $\mathrm{E}$ being required to generate an efficient substrate for these other nucleases. We also cannot exclude the possibility that the rne gene codes for a product that affects RNase E activity indirectly. For example, it could be a general regulator of ribonuclease activities, including RNase E, RNase K, and RNase F. Finally, the product of the rne gene could be a structural component of a ribonuclease complex (Jain et al. 1982), and its inactivation could affect the other components. The further purification of RNase E activity should help to clarify the relationship between the enzyme and the rne locus. In addition to the results presented here, a biochemical analysis of the RNA-enzyme interaction should help to elucidate the specificity determinants of this important endoribonuclease.

\section{Mechanism of RNase E processing at the - 71 site}

It is striking that in the CGU phage T4 mutant, the absence of cleavage at -71 was associated with the appearance of a series of cleavages (approximate positions at $-68,-78,-152$, and -185 ; Fig. 5). These cleavages were rne dependent and occurred at sites similar to the consensus cleavage sequence (see legend to Fig. 5). Significantly, these cleavages did not appear when the -71 processing was inhibited by mutations that disrupt the stem-loop. Thus, the stem-loop structure of the -71 site appears to be necessary for RNase E processing at these additional sites. This observation suggests an interesting possible mechanism for RNase E action. The enzyme could enter the RNA by binding to the stemloop. Once loaded on the message, it could, for example, remain bound to the stem-loop and scan the upstream RNA for cleavage sites. The -71 site is probably cleaved preferentially, because the other cleavages appeared only in the phage mutant CGU. RNase E is apparently unable to cleave downstream of the stem-loop in the $5^{\prime}$ leader because no rne-dependent cleavages were detected in the segment between the primer and the stem-loop. This segment contains several sequences resembling the consensus and is free of secondary structure. The apparent inability of the enzyme to cut $3^{\prime}$ of the stem-loop may explain why the processed gene 32 transcript is more stable than the upstream portion of the transcript (Mudd et al. 1988).

\section{Materials and methods}

\section{Bacteria and phage strains}

The E. coli RNase $\mathrm{E}^{+}$and RNase $\mathrm{E}^{\text {ts }}$ isogenic strains N3433 $\left\langle r n e^{+}\right)$and N3431 ( $\left.r n e^{\text {ts }}\right)$ (Goldblum and Apirion 1981) were used in most experiments. Infection of these strains was performed as described by Mudd et al. (1988). We used E. coli C600 (supE44; Appleyard 1954) and S/6 (su' ${ }^{-}$; Edgar and Lielausis 1964) for construction and growth of the mutant phages. Wild- 
type $\mathrm{T}_{4} \mathrm{D}^{+}$and the phage $\mathrm{T} 432^{-}$amSY6, which contains an amber mutation in the sixth codon of gene 32 , were from the Geneva collection.

\section{Plasmid constructions}

Two pairs of overlapping primers were annealed at their complementary 3' ends and extended as described in Oliphant and Struhl (1987). The two resulting double-stranded DNA fragments are a $\mathrm{BamHI}-\mathrm{HpaI}$ fragment-containing region from -95 to -30 and a HpaI-HindIII fragment-containing region from -29 to +20 of gene 32 (Ehretsmann et al. 1990). These fragments were digested separately with the appropriate pairs of restriction enzymes and ligated with pUC18 (Yannisch-Perron et al. 1985/ digested with BamHI and HindIII. The sequence of the insert was verified by DNA sequencing using a primer complementary to nucleotides +1 to +21 of gene 32 , plasmid DNA as template, and Sequenase (U.S. Biochemical). To remove the site of the rne-dependent cleavage in the polylinker of pUC18 (Ehretsmann et al. 1990) the 21 bp between the EcoRI and BamHI sites was deleted. This deletion was obtained by polymerase chain reaction (PCR) amplification of the plasmid with two primers each containing BamHI site at their 5' ends and complementary to opposite strands of the sequence flanking the deletion (Hemsley et al. 1989). After induction with IPTG, the resulting plasmid (pBG) directs the transcription from the lac promoter of a hybrid T4-lacZ transcript, which is drawn in Figure 1A. To construct the plasmids with mutant RNase E sites, a BglII-HpaI fragment was synthesized as described above, using oligonucleotides with mutations in the -71 site. These fragments were then used to replace the BamHI-HpaI fragment in pBG. Plasmids with mutations were identified by the loss of the BamHI and BglII sites and sequenced as described above. A further deletion was made in pBG to remove the 1 acZ sequence present upstream of the gene 32 sequence on the $\mathrm{T} 4$ lac $Z$ hybrid transcript. This deletion was made by PCR amplification of the plasmid using two primers containing a BgIII site at their $5^{\prime}$ end and complementary to the sequence flanking the deletion. After induction with IPTG, transcription from the lac promoter of the resulting plasmid, pCE, starts directly at the nucleotide -95 of the T4 sequence inserted (Fig. 1A). Mutations at the -71 RNase $\mathrm{E}$ site were introduced into this plasmid by replacing the BglII-HpaI region by a BgIII-HpaI fragment containing the mutation.

\section{Construction of the phage T4 mutants}

Because the constructs described above did not contain sufficient portions of gene 32 on each side of the -71 site to ensure efficient homologous recombination with the phage, a plasmid with a longer sequence of T4 was constructed. pAC301, a derivative of pGEM-3Zf- (Promega) containing the region -595 to +290 from gene 32 was constructed, and single-stranded DNA was made in the $d u t^{-}$ung $^{-} \mathrm{F}^{\prime}$ E. coli strain CJ236 using M13-R408 helper phage (Kunkel et al. 1987). An oligonucleotide bearing a mutation in the -71 RNase E site was annealed to this single-stranded DNA and extended with Klenow enzyme in the presence of T4 DNA ligase (Boehringer Mannheim). Transformants obtained with this reaction were sequenced to verify the introduction of the mutation in the -71 site. E. coli strain C600 transformed with the mutated plasmid was infected by T4 $32^{-}$amSY6. Recombinant phages in the progeny were selected on $\mathrm{S} / 6\left(\mathrm{su}^{-}\right)$strain, and phages containing the appropriate mutation in the -71 site were identified by RNA sequencing.

\section{General methods}

Restriction enzyme digests, ligation, transformation, plasmid preparation, ${ }^{32} \mathrm{P}$ end-labeling of DNA primers with T4 polynucleotide kinase, in vitro transcription with T7 RNA polymerase, PCR, and gel electrophoresis were performed essentially as described in Sambrook et al. (1989). 5'-End mapping by primer extension was conducted as described by Carpousis et al. (1989), with a primer complementary to nucleotides +1 to +21 of gene 32. The efficiency of processing was evaluated by careful comparison of several equally loaded gels and estimation of the ratio of the -71 band to the full-length message.

\section{RNA extraction}

Bacteria carrying the relevant plasmid were grown in M9S medium containing ampicillin $(50 \mu \mathrm{g} / \mathrm{ml})$ and $0.2 \%$ casamino acids (Champe and Benzer 1962 ) at $30^{\circ} \mathrm{C}$ to $2 \times 10^{8}$ cells $/ \mathrm{ml}$. RNA was then extracted $5 \mathrm{~min}$ after induction with IPTG $\left(10^{-3} \mathrm{M}\right)$ essentially as described by Hagen and Young (1978). For the RNA extraction at $43^{\circ} \mathrm{C}$, the cells at $2 \times 10^{8}$ were shifted from $30^{\circ} \mathrm{C}$ to $43^{\circ} \mathrm{C}$ and incubated $10 \mathrm{~min}$ before RNA extraction. RNA extraction from phage-infected cells was performed as described in Mudd et al. (1988).

\section{Partial purification of RNase $E$}

The cells used for purification of RNase $\mathrm{E}$ are $r n e^{+}, m e^{\mathrm{ts}}$, and $a m s^{t s}$ transductants of the RNase $\mathrm{I}^{-}$strain, DlO (A. Carpousis, G. Van Houwe, C. Ehretsmann, and H. Krisch, in prep.). The protocol employed is a modification of the procedure of Misra and Apirion (1979). Cells were grown in YK media to late log phase as described by Gesteland and Spahr (1969), washed, and frozen at $-70^{\circ} \mathrm{C}$. All subsequent steps were performed at $0-8^{\circ} \mathrm{C}$.

Frozen cells ( 25 grams) were ground with 62.5 grams of alumina. DNase I $(0.25 \mathrm{ml}$ of $1 \mathrm{mg} / \mathrm{ml})$ was added, and the paste was suspended in $87.5 \mathrm{ml}$ of $10 \mathrm{~mm}$ Tris- $\mathrm{HCl}(\mathrm{pH} 7.5), 10 \mathrm{~mm}$ magnesium acetate, $10 \mathrm{~mm}$ potassium chloride, $1 \mathrm{~mm}$ phenylmethylsulfonyl fluoride (PMSF), and $5 \mu \mathrm{g} / \mathrm{ml}$ of aprotinin. The broken cell suspension was centrifuged for $20 \mathrm{~min}$ at $6000 \mathrm{rpm}$ in a Sorval GSA rotor. The supernatant from the low-speed spin was then centrifuged for $30 \mathrm{~min}$ at $16,000 \mathrm{rpm}$ in a Sorval SS-34 rotor to obtain the $30,000 \mathrm{~g}$ supernatant. The $30,000 \mathrm{~g}$ supernatant was adjusted to $0.6 \mathrm{M}$ ammonium chloride by drop-wise addition of a $5 \mathrm{~m}$ stock with stirring on ice. Stirring was continued for another $30 \mathrm{~min}$. The preparation was then centrifuged for $2 \mathrm{hr}$ at $45,000 \mathrm{rpm}$ in a Beckman Ti- 60 rotor to obtain the $200,000 \mathrm{~g}$ supernatant. The $200,000 \mathrm{~g}$ supernatant was fractionated with solid ammonium sulfate ( 24 grams $/ 100 \mathrm{ml}$ ). The ammonium sulfate pellet was suspended in $10 \mathrm{ml}$ of $10 \mathrm{mM}$ Tris- $\mathrm{HCl}$ (pH 7.5), $25 \mathrm{~mm}$ ammonium chloride, $0.1 \mathrm{mM}$ EDTA, $0.1 \mathrm{mM} \mathrm{DTT}$, and $0.5 \mathrm{M}$ glycerol and chromatographed in the same buffer on a $1.6 \times 65-\mathrm{cm}$ Sephadex G150 column. RNase E activity eluted in the void volume. Individual fractions from the void volume were diluted to $0.4 \mathrm{mg} / \mathrm{ml}$ of protein in the same buffer supplemented with BSA $(1 \mathrm{mg} / \mathrm{ml})$ and yeast RNA $(0.4$ $\mathrm{mg} / \mathrm{ml}$ ). The fractions were aliquoted and frozen at $-70^{\circ} \mathrm{C}$.

RNase E activity was purified $\sim 100$-fold, based on an assay using a 9S rRNA substrate (data not shown). The Sephadex G150 fraction is still relatively crude, as evidenced by the presence of 20-40 major polypeptides on an SDS-polyacrylamide gel stained with Coomassie blue (data not shown). The fractionation of RNase E differs in two significant ways from the results published previously by Misra and Apirion (1979). (1) RNase E activity pellets with the ribosomes in low salt. Adjusting the $30,000 \mathrm{~g}$ supernatant to $0.6 \mathrm{M}$ ammomium chloride before the 
$200,000 \mathrm{~g}$ centrifugation gives a 5 - to 10 -fold increase in the yield of activity. (2) The apparent native molecular mass of the enzyme is $>300,000$, based on its elution in the void volume of the Sephadex G150 column, but we cannot exclude the possibility that this is the result of aggregation of the enzyme. We have included the protease inhibitors PMSF and aprotinin in the initial step of our protocol. These inhibitors may be important for protecting RNase E from proteolysis. This might explain the differences in the fractionation. A detailed account of the purification and further characterization of RNase E (A. Carpousis, G. Van Houwe, C. Ehretsmann, and H. Krisch, in prep.).

\section{In vitro RNase E assay}

Transcripts bearing mutation in the -71 site were synthesized in vitro using T7 RNA polymerase and DNA template generated by PCR. Two oligonucleotides complementary to sequence +1 to +20 and -95 to -78 of gene 32 were used to amplify a fragment-containing region from -95 to +20 on the the different mutant plasmids. The primer complementary to the $5^{\prime}$ end of the T4 fragment also contained a T7 promoter. The DNA fragment amplified by PCR was isolated and transcribed in vitro with T7 RNA polymerase (Sambrook et al. 1989). The synthetic transcripts were incubated at $30^{\circ} \mathrm{C}$ or $45^{\circ} \mathrm{C}$ for $15 \mathrm{~min}$ with a fraction of the Sephadex column that processes 9S RNA to the precursor of 5 S rRNA (A. Carpousis, G. Van Houwe, C. Ehretsmann, and $\mathrm{H}$. Krisch, in prep.). The experiments were carried out at $45^{\circ} \mathrm{C}$ because the inactivation of the mutant enzyme was more complete at this temperature than at $43^{\circ} \mathrm{C}$, which is the temperature of inactivation in vivo. The $25-\mu$ l reaction contained $25 \mathrm{mM}$ Tris- $\mathrm{HCl}\left(\mathrm{pH} 7.5\right.$ for incubation at $30^{\circ} \mathrm{C}$ or $\mathrm{pH} 7.9$ at $45^{\circ} \mathrm{C}$ ), $125 \mathrm{mM} \mathrm{NH}_{4} \mathrm{Cl}, 2.5 \mathrm{~mm} \mathrm{MgCl}_{2}, 0.1 \mathrm{~mm}$ EDTA, $0.1 \mathrm{mM}$ DTT, $100 \mathrm{~mm}$ glycerol, $0.4 \mathrm{mg} / \mathrm{ml}$ of yeast RNA, and $0.04 \mathrm{mg} /$ $\mathrm{ml}$ of protein from the active Sephadex fraction. After incubation, the proteins were extracted with phenol and the RNA was ethanol precipitated before analysis by primer extension.

\section{Acknowledgments}

We thank R.H. Epstein for discussions and criticism of the manuscript and for generously providing support and facilities. The skillfull technical assistance of $\mathrm{C}$. Fumey is particularly appreciated. G. Van Houwe's technical contribution and advice are gratefully acknowledged. We also thank P. Prentki and E. Käs for helpful comments on the manuscript, O. Jenni and F. Ebener for the preparation of the figures, and D. Rifat for preparing the oligonucleotides. This work was supported by a grant from the Swiss National Science Foundation (no. 3.188.88). Additional support was provided by the Department of Public Instruction of the State of Geneva.

The publication costs of this article were defrayed in part by payment of page charges. This article must therefore be hereby marked "advertisement" in accordance with 18 USC section 1734 solely to indicate this fact.

\section{References}

Apirion, D. 1978. Isolation, genetic mapping and some characterization of a mutation in Escherichia coli that affects the processing of ribonucleic acids. Genetics 90: 659-671.

Appleyard, R.K 1954. Segregation of new lysogenic types during growth of a doubly lysogenic strain derived from Escherichia coli K12. Genetics 39: 440.

Babitzke, P. and S.R. Kushner. 1991. The ams (altered mRNA stability) protein and ribonuclease $\mathrm{E}$ are encoded by the same structural gene of Escherichia coli. Proc. Natl. Acad. Sci. 88: $1-5$.

Bardwell, J.C.A, P. Régnier, S. Chen, Y. Nakamura, M. Grunberg-Manago, and D. Court. 1989. Autoregulation of RNase III operon by mRNA processing. EMBO I. 8: 3401-3407.

Belasco, I.G. and C.F. Higgins. 1988. Mechanisms of mRNA decay in bacteria: A perspective. Gene 72: 15-23.

Belin, D., E.A Mudd, P. Prentki, Yu Yi-Yi, and H.M. Krisch. 1987. Sense and antisense transcription of bacteriophage T4 gene 59. I. Mol. Biol. 194: 231-243.

Blumer, K.J. and D.A. Steege. 1989. Recognition and cleavage signals for mRNA processing lie within locals domains of the phage f1 RNA precursors. I. Biol. Chem. 264: 2077020777.

Brun, Y.V., H. Sanfaçon, R. Breton, and I. Lapointe. 1990. Closely spaced and divergent promoters for an aminoacyltRNA synthetase gene and a tRNA operon in Escherichia coli. J. Mol. Biol. 214: 845-864.

Cannistraro, V.I. and D. Kennel. 1989. Purification and characterization of ribonuclease $M$ and mRNA degradation in Escherichia coli. Eur. J. Biochem. 181: 363-370.

Carpousis, A.J., E.A. Mudd, and N.M. Krisch. 1989. Transcription and messenger RNA processing of bacteriophage T4 gene 59. Mol. Gen. Genet. 219: 39-48.

Champe, S.P. and S. Benzer. 1962. Reversal of mutant phenotypes by 5-fluorouracil: An approach to nucleotide sequences in messenger RNA. Proc. Natl. Acad. Sci. 48: 532546.

Chauhan, A.K. and D. Apirion. 1989. The gene for a small stable RNA (10Sa RNA) of Escherichia coli. Mol. Microbiol. 3: $1481-1485$.

Chauhan, A.K., A Miczak, L. Taraseviciene, and D. Apirion. 1991. Sequencing and expression of the rne gene of Escherichia coli. Nucleic Acids Res. 19: 125-129.

Claverie-Martin, F., M.R. Diaz-Torres, S.D. Yancey, and S.R. Kushner. 1989. Cloning of the altered mRNA stability (ams) gene of Escherichia coli K-12. I. Bacteriol. 171: 5479-5486.

. 1991. Analysis of the altered mRNA stability (ams) gene from Escherichia coli. I. Biol. Chem. 266: 2843-2851.

Donovan, P. and S.R. Kushner. 1986. Polynucleotide phosphorylase and ribonuclease II are required for cell viability and mRNA turnover in Escherichia coli K-12. Proc. Natl. Acad. Sci. 83: 120-124.

Edgar, R.S. and I. Lielausis. 1964. Temperature-sensitive mutants of bacteriophage T4D: Their isolation and genetic characterization. Genetics 49: 649-662.

Ehretsmann, C., A.J. Carpousis, and H.M. Krisch. 1990. Mutational analysis of a RNase E dependent cleavage site from a bacteriophage T4 mRNA. NATO ASI (Adv. Sci. Inst.) Ser. Ser. $H$ Cell Biol. H49: 21-30.

Faubladier, M., C. Kaymeuang, and J.-P. Bouché. 1990. Escherichia coli cell division inhibitor dicF-RNA of the dicB operon. Evidence for its generation in vivo by transcription termination and by RNase III and RNase E dependent processing. J. Mol. Biol. 212: 461-471.

Gesteland, R.F. and P.F. Spahr. 1969. Translation of R-17 fragments. Cold Spring Harbor Symp. Quant. Biol. 34: 707-716.

Ghora, B.K and D. Apirion. 1978. Structural analysis and in vitro processing to 5 rRNA of a 9S RNA molecule isolated from an me mutant of $E$. coli. Cell 15: 1055-1066.

Goldblum, K. and D. Apirion. 1981. Inactivation of the ribonucleic acid-processing enzyme ribonuclease E blocks cell division. J. Bacteriol. 146: 128-132.

Gurevitz, M., N. Watson, and D. Apirion. 1982. A cleavage site of ribonuclease $F$, a putative processing endoribonuclease from Escherichia coli. Eur. J. Biochem. 124: 553-559. 
Gurevitz, M., K.J. Swatantra, and D. Apirion. 1983. Identification of a precursor molecule for the RNA moiety of the processing enzyme RNase P. Proc. Natl. Acad. Sci. 80: 44504454.

Hagen, F.S. and E.T. Young. 1978. Effect of RNase III on efficiency of translation of bacteriophage $\mathrm{T} 7$ lysozyme mRNA. J. Virol. 26: 793-804.

Hemsley, A., N. Amheim, M.D. Toney, G. Cortopassi, and D.J. Galas. 1989. A simple method for site-directed mutagenesis using the polymerase chain reaction. Nucleic Acids Res. 17: 6545-6551.

Jain, S.K. B. Pragai, and D. Apirion. 1982. A possible complex containing RNA processing enzymes. Biochem. Biophys. Res. Commun. 106: 768-778.

Kokoska, R.J., K.J. Blumer, and D.A. Steege. 1990. Phage f1 mRNA processing in Escherichia coli: Search for the upstream products of endonuclease cleavage, requirement for the product of the altered mRNA stability (ams) locus. Biochimie 72: 803-811.

Kunkel, T.A., J.D. Roberts, and R.A. Zakour. 1987. Rapid and efficient site-specific mutagenesis without phenotypic selection. Methods Enzymol. 154: 367-382.

Loayza, D., A.J. Carpousis, and H.M. Krisch. 1991. Gene 32 transcription and mRNA processing in T4 and related bacteriophages. Mol. Microbiol. 5: 715-725.

Lundberg, U., A. von Gabain, and O. Melefors. 1990. Cleavages in the $5^{\prime}$ region of the ompA and bla mRNA control stability: Studies with an $E$. coli mutant altering mRNA stability and a novel endoribonuclease. EMBO J. 9: 2731-2741.

Mackie, G.A. 1991. Specific endonucleolytic cleavage of the mRNA for ribosomal protein $\mathrm{S} 20$ of Escherichia coli requires the product of the ams gene in vivo and in vitro. I. Bacteriol. 173: 2488-2497.

McPheeters, D.S., G.D. Stormo, and L. Gold. 1988. Autogenous regulatory site on the bacteriophage $\mathrm{T} 4$ gene 59 messenger RNA. J Mol. Biol. 201: 517-535.

Misra, T.K and D. Apirion. 1979. RNase E, an RNA processing enzyme from E. coli. J. Biol. Chem. 254: 11154-11159.

Mudd, E.A., P. Prentki, D. Belin, and H.M. Krisch. 1988. Processing of unstable bacteriophage $\mathrm{T} 4$ gene 59 species into a stable species requires Escherichia coli ribonuclease E. EMBO J. 7: 3601-3607.

Mudd, E.A., A.J. Carpousis, and H.M. Krisch. 1990a. Escherichia coli RNase $\mathrm{E}$ has a role in the decay of bacteriophage $\mathrm{T} 4$ mRNA. Genes \& Dev. 4: 873-881.

Mudd, E.A., H.M. Krisch, and C.F. Higgins. 1990b. RNase E, an endoribonuclease, has a general role in the chemical decay of Escherichia coli mRNA: Evidence that me and ams are the same genetic locus. Mol. Microbiol. 4: 2127-2135.

Newbury, S.F., N.H. Smith, E.C. Robinson, I.D. Hiles, and C.F. Higgins. 1987. Stabilization of translationally active mRNA by prokaryotic REP sequences. Cell 48: 297-310.

Nilsson, G., U. Lundberg, and A. von Gabain. 1988. In vivo and in vitro identity of site specific cleavages in the $5^{\prime}$ non-coding region of ompA and bla mRNA in Escherichia coli. EMBO I. 7: 2269-2275.

Oliphant, R.A. and K. Struhl. 1987. The use of random-sequence oligonucleotides for determining consensus sequences. Methods Enzymol. 155: 568-582.

Ono, M. and M. Kuwano. 1979. A conditional lethal mutation in an Escherichia coli strain with a longer chemical lifetime of mRNA. J. Mol. Biol. 129: 343-357.

- 1980. Chromosomal location of a gene for chemical longevity of messenger ribonucleic acid in a temperature-sensitive mutant of Escherichia coli. J. Bacteriol. 142: 325-326.

Plamann, M.D. and G.V. Stauffer. 1990. E. coli gly $A$ mRNA decay: The role of $3^{\prime}$ secondary structure and the effects of the pnp and $r n b$ mutations. Mol. Gen. Genet. 220: 301-306.

Portier, C., L. Dondon, M. Grunberg-Manago, and P. Régnier. 1987. The first step in the functional inactivation of the Escherichia coli polynucleotide phosphorylase messenger is a ribonuclease III processing at the 5' end. EMBO I. 6: 21652170.

Pragai, B. and D. Apirion. 1982. Processing of bacteriophage T4 transfer RNAs. I. Mol. Biol. 154: 465-484.

Régnier, P. and M. Grunberg-Manago. 1989. Cleavage by RNase III in the transcripts of the metY-nusA-infB operon of $E$. coli release the tRNA and initiates the decay of the downstream mRNA. I. Mol. Biol. 210: 293-302.

Régnier, P. and E. Hajnsdorf. 1991. Decay of mRNA encoding ribosomal protein $\mathrm{S} 15$ of Escherichia coli is initiated by an RNase E-dependent endonucleolytic cleavage that removes the $3^{\prime}$ stabilizing stem and loop structure. J. Mol. Biol. 217: 283-292.

Romaniuk, P., P. Lowary, H.-N. Wu, G. Stormo, and O.C. Uhlenbeck. 1987. RNA binding site of R17 coat protein. Biochemistry 26: 1563-1569.

Sambrook, J., E.F. Fritsch, and T. Maniatis. 1989. Molecular cloning: A laboratory manual, 2nd ed. Cold Spring Harbor Laboratory, Cold Spring Harbor, New York.

Schmeissner, U., K. McKenney, M. Rosenberg, and D. Court. 1984. Removal of a terminator structure by RNA processing regulates int gene expression. J. Mol. Biol. 176: 39-53.

Srivastava, R.K., A. Miczak, and D. Apirion. 1990. Maturation of precursor 10Sa RNA in Escherichia coli is a two-step process: The first reaction is catalyzed by RNaseIII in presence of $\mathrm{Mn}^{2+}$. Biochimie 72: 791-802.

Subbarao, M.N. and D. Apirion. 1989. A precursor for a small stable RNA (10Sa RNA) of Escherichia coli. Mol. Gen. Genet. 217: 499-504.

Tang, C.K. and D.E. Draper. 1989. Unusual mRNA pseudoknot structure is recognized by a protein translational repressor. Cell 57: 521-536.

Taraseviciene, L., A. Miczak, and D. Apirion. 1991. The gene specifying RNase $\mathrm{E}$ ( $\mathrm{rne}$ ) and a gene affecting mRNA stability (ams) are the same gene. Mol. Microbiol. 5: 851-855.

Tomcsànyi, T. and D. Apirion. 1985. Processing enzyme ribonuclease E specifically cleaves RNA I an inhibitor of primer formation in plasmid DNA synthesis. $J$. Mol. Biol. 185: 713720

Yannisch-Perron, C., J. Vieira, and J. Messing. 1985. Improved M13 phage cloning vector and host strains: Nucleotides sequences of the M13mp18 and pUC19 vectors. Gene 33: 103119.

Zuker, M. and P. Stiegler. 1981. Optimal computer folding of large RNA sequences using thermodynamics and auxiliary information. Nucleic Acids Res. 9: 133-148. 


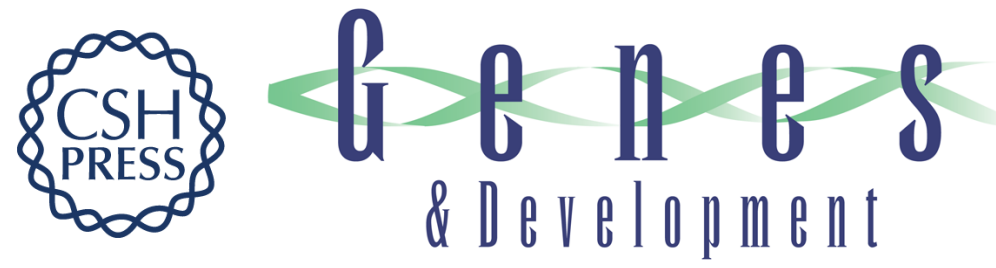

\section{Specificity of Escherichia coli endoribonuclease RNase E: in vivo and in vitro analysis of mutants in a bacteriophage T4 mRNA processing site.}

C P Ehretsmann, A J Carpousis and H M Krisch

Genes Dev. 1992, 6:

Access the most recent version at doi:10.1101/gad.6.1.149

References This article cites 56 articles, 17 of which can be accessed free at: http://genesdev.cshlp.org/content/6/1/149.full.html\#ref-list-1

License

Email Alerting Service

Receive free email alerts when new articles cite this article - sign up in the box at the top right corner of the article or click here.

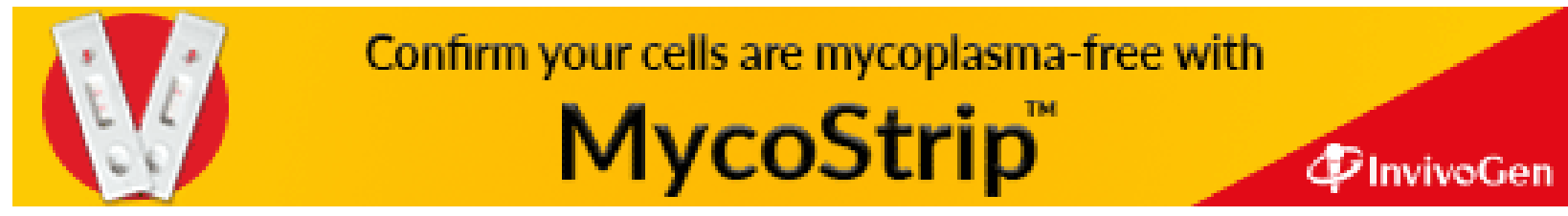

